\title{
Evaluation of Certified Teachers' Perfomance at SMPN 6 Luwuk Banggai Regency, Indonesia
}

\author{
Suhartini Salingkat* \\ Tompotika University, Luwuk Banggai Regency, Central Sulawesi, Indonesia \\ Corresponding author: Suhartini Salingkat, E-mail: suhartinisalingkat@gmail.com
}

\section{ARTICLE INFO}

Article history

Received: July 07, 2017

Accepted: October 04, 2017

Published: October 31, 2017

Volume: 5 Issue: 4

Conflicts of interest: None

Funding: None

\begin{abstract}
This study investigated certified teachers' performance at SMPN 6 Luwuk of Banggai Regency, with a focus on the teachers' performance in planning the lesson, implementing the lesson, and conducting the lesson evaluation. It lasted for nine months, from March to December 2011. Qualitative method was used. More specifically, the evaluation research method was followed which involves collecting, analyzing, and interpreting data for decision making. The evaluation system used in this study was based on the quality of the certified teachers' performances. The real condition in the field is that many of the certified teachers are still unable to design lessons and implement them professionally as expected from certified teachers. Currently there are many teachers in need of trainings. This study showed that the quality of the performance of the certified teachers in SMPN 6 Luwuk in planning the lesson was low. This could indicate that the certification process has not yet resulted in an increase in the quality of performance of the certified teachers, particularly as long as the quality of their performance in planning lessons is concerned.
\end{abstract}

Key words: Teacher's Performance Evaluation, Teacher's Certification, Learning Activities

\section{INTRODUCTION}

Regulation National Education System No. 20 of 2003 is obligated to provide the service and easiness, and ensure the delivery of qualified education for each and every citizen without any discrimination. One of the efforts to increase the quality of education is that every educational institution has to meet the national minimum standard. According to Government Regulation No 19 of 2005 on National Standard of Education Article 2, the national standard of education comprises: (a) content standard,(b) process standard, (c) output competencies standard, (d) educators and educational staff standard, (e) infrastructure and facilities standard, (f) management standard, (g) financing standard, and (h) educational assessment standard. Furthermore, according to Clause 2, evaluation, accreditation, and certification should be implemented to ensure education quality meets the national standard of education. Additionally, Article 3 of the regulation explains that the national standard of education serves as the basis for planning, implementing, evaluating, and monitoring of education in order to meet the national standards. One of the government policies in increasing the quality of education is through increasing the quality of educational management. Educational management has to be holistically viewed by considering national standards which are put into action through well-thought policy. The standard of primary and middle education management set by the government was stipulated in the Regulation No. 19 issued by Ministry of National Education in 2007 on six primary standards in management of education; namely, program planning, implementation of the workplan, monitoring and evaluation, and school leadership, management information system, specific assessment.

Teachers and education supporting staff play integral roles in increasing the quality of educational management. The teacher is indeed one of the determining factors in increasing the quality of education. Teacher as manager have to have sufficient competencies in mastering, and comprehending knowledge, skills, and attitude manifested in their roles as teachers. A teacher is expected to have (1) pedagogic competencies in managing the learners' learning process, which means that the teacher should perform to the best of her ability to observe human values than mere material values; (2) personal competencies by upholding positive attitude and values, such as, stability, dignity, maturity, honesty, democracy, and supportiveness; (3) social competencies which allow her to communicate and interact effectively, implement the value of togetherness, and make use of information and communication technology; (4) professional competencies which demonstrate the teacher's ability to master a specific field of knowledge, technology, arts and culture. This also means the teacher widely and comprehensively masters the subject that she teaches in line with the standards and knows the concepts and methods of that particular subject.

What can be asked regarding the increasing percentage of outputs almost in all units of education is whether this in- 
crease can be credited to the increasing performance of certified teachers or rather this increase of teachers' performance is only due to their preparation for participating in teachers' certification program.

Certification is given only to teachers who have met the criteria as professional teachers and have undoubted teaching competence. This program is implemented simultaneously in all districts in Indonesia, including Banggai district. The teacher certification program in Banggai district started in 2006, followed by 22 teachers, consisting of 11 primary school teachers and 11 junior high school teachers. After running for approximately 5 years until the end of 2010 , the number of teachers in Banggai district from all levels of education that had been certified reached1441 teachers, or $25.63 \%$ of the total number of teachers $(\mathrm{n}=5621)($ Dinas Pendidikan Pemuda dan Olahraga, 2011).

Based on the observation of this researcher of what is currently happening in junior high schools in Luwuk Regency, particularly in SMPN6 Luwuk, the teacher certification program has not yet produced the expected changes. Ideally, it is expected that certified teachers would have performed better than those uncertified teachers. Certified teachers are expected to be professional in implementing their role, especially in planning, implementing, and evaluating the lesson. This condition has led to a series of questions on how exactly the certification program is implemented. Is the ultimate objective to improve teacher's welfare? What are the shortcomings of this certification program? To what extent has this program brought impact on the performance of certified teachers and those of uncertified teachers in Banggai Regency? These questions have to be systematically and procedurally dealt with.

\section{Objectives}

This study investigated the performance of certified teachers in SMPN6 Luwuk Banggai. Specifically it focused on the teachers' performance in planning, implementing, and evaluating the lesson. The condition in the field tends to reveal that there are still many certified teachers who are unable to design lesson plans and implement their lessons properly, or in short, they are not professional yet in their field; and that there are many teachers that are currently in need of assistance through training.

This research can provide information about the performance of certified teachers especially in planning and implementing the learning process that can be used as a basis in determining the policy by the authorities in the future. Besides that, it also provides an input to the education office in Banggai district to encourage teachers to work well in accordance with their duties and responsibilities.

\section{Research Questions}

Based on the research background and focus of study above, questions of this study are:

1. How is the quality of certified teachers' performance in SMPN6 Luwuk of Banggai Regency in planning the lesson?
2. How is the quality of certified teachers' performance in SMP N 6 Luwuk of Banggai Regency in implementing the lesson activities?

\section{LITERATURE REVIEW}

\section{Conceptual Description of Evaluation}

Evaluation is defined as a process in determining the adequacy of a program, its objectives, procedure, approach, and functions (Stufflebeam, et al., 1997). As a process of assessing something, evaluation is based on the criteria or objective standard predetermined to take decisions against the object being evaluated (Djali and Ramly, 2000). Educational evaluation is a systematic investigation activity on the adequacy and appropriateness of an educational objective. Education objectives in a unit of aducation are a blend of the real conditions and the conditions that may arise. In establishing an educational objective, well-thought consideration is needed including the unit's ability in achieving that objective. Based on these definitions, it can be concluded that evaluation is a process of collecting, analyzing, and interpreting information to reach certain decisions. Decision making in regard to evaluation is an action taken by a person or an institution in order to improve a certain program.

\section{Conceptual Description of Performance}

Patricia(1993) proposed that performance is an action, or an accomplishment shown by a person through their significant skills. Whitmore, Dwi, and Louis (1997) proposed a similar definition, in which he proposed that performance is one's activity in implementing their functions in a job assigned to him. It means people selected certain jobs because they need those jobs for their own interest or that they feel able to implement it.

According to Yamin (2010), performance is work output that can be achieved by a person or a group of people in organization qualitatively and quantitatively. Performance also has several other interchangeable synonyms such as: 1) work achievement, 2) work implementation; 3) work attainment; 4) work Output (Serdamayanti, 2001).

According to Micthell (1989), performance has several characteristics such as: (1) work quality, (2) punctuality, (3) pertinence, (4) workability, and (5) communication.

Performance is one's achievement in their tasks' implementation in accordance with the authority and responsibility bestowed upon that person in the efforts to achieve the organizational goals, in which the indicator are to accomplished the tasks, obeying the procedure and observing the regulations, has work initiatives, maintain the work quality, feedback toward the increase of demand in work, and achieving the objectives set in work plan (Micthell, 1989).

Based on the above description of performance by some scholars, performance can be defined as the way one's work ability to work showed by particular person during certain period of times which in accordance with the set criteria and indicators to achieve certain objectives. Within the context of teacher's performance, performance could be described as 
achievement or a teacher's ability in planning the lesson and implementing the learning process.

\section{Conceptual Description of Performance Evaluation}

Landy and Fan (2000) as cited in Dale (2000) wrote that performance evaluation is conducted in all stages of activities, both the process and output stages. From this assessment, data on performance could be gained. Data on performance at least are used for three main purposes: administrative purposes, supervision and counseling purposes, and research purposes. Performance measurement according to Manullang (2001) are comprised of: 1) quality; 2) ability; 3) work quantity; 4) knowledge on the tasks; 5) cooperation; 6) initiative; 7) adaptability; 8) existence; 9) planning and organizing; and 10) healthiness.

Therefore, it can be said that performance evaluation is a process to assess the work result or work ability of a person based on the criteria which have previously been determined to achieve certain objective. There are several variables to be considered in work evaluation namely: work quality, ability, existence, punctuality, cooperation, obedience, and planning. In relation to teacher, performance evaluation is a process to assess the work result or work product of a teacher in planning the lesson, implementing the lesson, and evaluating the learning process and developing the learners' potentials based on the predetermined criteria to achieve the objectives.

\section{Policy for Standard of Learning Implementation Process}

According to the government Regulation No. 19 of 2005 on National Standard of Education, one of the standards that have to be developed is the standard of learning implementation in each educational unit in order to achieve the standard competencies for output. The standard process regulates the criteria of minimal process of learning in primary and secondary educational unit, which encompass the planning, implementation, evaluation, and monitoring of the effective and efficient learning process. This process standard is applicable to formal education.

\section{Planning the learning process}

Learning process planning consists of syllabus and lesson plan (RPP) which contains the identity of the subject, competencies standard (SK), basic competencies (KD), competencies' achievement indicator, learning objectives, learning material, time allocation, learning methods, learning activities, assessment of learning output, and learning sources.

\section{Learning implementation}

Implementation of learning is the implementation of RPP which consisted of introduction, core activities, and closing activities.

\section{Teacher's Certification}

Mulyasa (2009) has written down that teachers' standard of competencies and teachers' certification is implemented in order to create good and professional teacher, who has the competencies to implement the function and objectives of the school, especially the objectives of education in general, according to the demand of the society. This is also backed up by Uno (2009) who stated that:

Professional competencies of a teacher is a set of ability that has to be mastered by a teacher in order for her/him to be able to properly implement her/his tasks. Competencies that have to be mastered by a teacher consists of three types of competencies namely, personal competencies, social competencies, and professional competencies. A teachers' success in implementing his or her profession is largely determined by these three competencies with the emphasison his/her ability to teach.

According to Semiawan (1985) as an instructional system, there are several components in teaching namely, teaching objectives, teaching materials, teaching method, teaching tools and teaching media, evaluation of teaching and teaching situation. In order for those components to be fully developed in teaching and learning process, a teacher is required to have various teaching ability. This ability is known as performance or competencies.

Based on several of these notions on teacher' teaching performance, it appears that the quality of the teaching performance as reflected in teacher's behavior or activity in implementing the teaching program to achieve effective learning.

Based on Teacher and Lecture Regulation RI No. 14 of 2005, it is stated that certification is a process to award teaching certificate for teachers and lecturers as professional workers. Teachers' certification can be defined as an acknowledgement process that a teacher has obtained competencies to implement educational services in certain educational unit, following his/her passing the competencies test administered by certification institution.

Based on those descriptions, teachers' certification is a process to award a certificate for teacher who has and masters four competencies namely, professional competencies, personal competencies, social competencies, and pedagogic competencies in implementing the schools' functions and objectives as well as attaining the educational objectives.

Teachers' performance evaluation criteria are presented in Table 1.

\section{RESEARCH METHOD}

This study was conducted in SMPN6 Luwuk for nine months, from March to December 2011.

This study used qualitative approach. The research method is evaluation research by collecting, analyzing, and interpreting the information obtained to make decision. The evaluation system is used in this research due to result quality (product) of certified teacher's performance.

\section{Research Instrument}

The research instrument used in this study is the observation guideline and documentation, as well as open-ended interview. The instruments are presented in Table 2. 
Table 1. Criteria and indicator of Teacher's performance evaluation

\begin{tabular}{|c|c|c|c|}
\hline No. & Evaluated components & Indicator & Criteria \\
\hline \multirow[t]{29}{*}{1} & $\begin{array}{l}\text { Quality of planning the } \\
\text { learning activities }\end{array}$ & $\begin{array}{l}\text { Competencies } \\
\text { standard (SK) }\end{array}$ & In accordance with the SI \\
\hline & & $\begin{array}{l}\text { Basic } \\
\text { competencies }(\mathrm{KD})\end{array}$ & In accordance with SI \\
\hline & & Indicator & Measurable \\
\hline & & & Operational word \\
\hline & & & Refer to KD and SK \\
\hline & & Learning objective & Contain process and product elements \\
\hline & & & Specific and stated in form of behavior \\
\hline & & & Contains learning experience to achieve objective \\
\hline & & & Considers the time to attain objective \\
\hline & & & Realistic and understand as learning activity \\
\hline & & Learning tools & Contains knowledge \\
\hline & & & $\begin{array}{l}\text { The value process is in line with the development of science and } \\
\text { technology }\end{array}$ \\
\hline & & & Systematic and organized \\
\hline & & & In accordance with the SK and KD \\
\hline & & & Refer to the objective \\
\hline & & $\begin{array}{l}\text { Selection method/ } \\
\text { strategy }\end{array}$ & In line with the objective \\
\hline & & & Adjusted with the lesson material \\
\hline & & & Adjusted with the condition or the children's need \\
\hline & & & Applicable \\
\hline & & Activity steps & Consists of opening, content, and closing \\
\hline & & & In accordance with the method used \\
\hline & & & Time allocation is arranged proportionally \\
\hline & & & Give enrichment \\
\hline & & $\begin{array}{l}\text { Media and source of } \\
\text { learning }\end{array}$ & Adapted to the learning objective \\
\hline & & & In accordance with lesson material \\
\hline & & & Suitable with the class condition \\
\hline & & Evaluation & The instruments refer to the learning objective \\
\hline & & & Mentioned the form of evaluation \\
\hline & & & Mentioned the type of evaluation \\
\hline \multirow[t]{9}{*}{2} & Quality of the & Opening the lesson & Prepare the learners \\
\hline & & & Conduct apperception \\
\hline & & & Describe the basic competencies and the objectives \\
\hline & & & $\begin{array}{l}\text { Mentioned the materials that will be covered and the description on the } \\
\text { activity }\end{array}$ \\
\hline & & Exploration & $\begin{array}{l}\text { Involve students in searching for information and learn from various } \\
\text { sources }\end{array}$ \\
\hline & & & Use various approach in learning, learning media and \\
\hline & & & Actively involve students in various learning activities \\
\hline & & & $\begin{array}{l}\text { Facilitate students in conducting experiments in the laboratory, studio, } \\
\text { and in the field. }\end{array}$ \\
\hline & & Elaboration & Habituate students to read and write through various meaningful tasks \\
\hline
\end{tabular}


Table 1. (Continued)

\begin{tabular}{|c|c|c|c|}
\hline No. & Evaluated components & Indicator & Criteria \\
\hline & & & $\begin{array}{l}\text { Facilitate students through tasks assignment, discussion, etc., to stimulate } \\
\text { new ideas both orally and in written }\end{array}$ \\
\hline & & & $\begin{array}{l}\text { Provide chances to think, analyze, and solve the problems and act without } \\
\text { fear }\end{array}$ \\
\hline & & & Facilitate students in learning cooperatively and collaboratively. \\
\hline & & & $\begin{array}{l}\text { Facilitate students to compete healthily to increase their learning } \\
\text { achievement }\end{array}$ \\
\hline & & & $\begin{array}{l}\text { Facilitate students in composing explorative report both orally and in } \\
\text { writing (individual/group) }\end{array}$ \\
\hline & & & Facilitate students to present their work result individually or in group \\
\hline & & & $\begin{array}{l}\text { Facilitate students in conducting exhibition, tournament, festival and } \\
\text { showing the products of their work }\end{array}$ \\
\hline & & & Facilitate students to create their pride and confidence \\
\hline & & Confirmation & $\begin{array}{l}\text { Provide positive feedback and affirmation orally, in writing, through } \\
\text { symbols, or through prizes toward the students' success }\end{array}$ \\
\hline & & Closing the lesson & $\begin{array}{l}\text { Act as resource person and moderator to answer difficult questions posed } \\
\text { by the students }\end{array}$ \\
\hline & & & Assist students in solving their problems \\
\hline & & & $\begin{array}{l}\text { Motivate students that are less active and provide information for the } \\
\text { students to explore }\end{array}$ \\
\hline & & & Assign structured tasks \\
\hline & & & Inform the lesson planed for the next meeting \\
\hline
\end{tabular}

Table 2. Guidelines for observation and interview instrument on certified teacher's performance

\begin{tabular}{llll}
\hline $\begin{array}{l}\text { Teacher's performance } \\
\text { criteria }\end{array}$ & Data source & Indicator & Data collection method \\
\hline Quality of lesson plan activity & Lesson plan documents & $\begin{array}{l}\text { Syllabus identity } \\
\text { Standard competencies }\end{array}$ & Observation and interview \\
& & Indicator & Learning material \\
& & Lesson plan activity & Time allocation \\
& & Source of materials & Observation and interview \\
Quality of learning activity & Result of observation of the & Opening & Core activities \\
implementation & learning activity implementation & Closing & \\
& & &
\end{tabular}

In accordance with the focus of this study, the data needed in this research are aspects related to teacher's performance. Whereas the informants in this study are teachers at SMPN6 Luwuk of Banggai Regency.

The data collection methods were interview, observation, and document study. To analyze the data in this research the data were descriptively analyzed by comparing the data obtained from observation, documentation, and interview form certified teachers with the uncertified teachers.

\section{RESEARCH FINDINGS AND DISCUSSION}

\section{Description of Research Output}

\section{Result on the lesson planning evaluation}

Lesson plan has to be prepared by teacher are syllabus and RPP. To evaluate the quality of the syllabus, observation sheet was used. The observation result on the document of teacher's lesson plan between certified teachers and uncertified teachers were separated then analyzed based on the set of assessment tools. The recapitulation of the observation result on the lesson plan documents (Syllabus/RPP) of the certified teachers is presented in the following table:

Based on Table 3 above, it is evident that overall the ability of certified teachers in SMPN 6 Luwuk are good in developing the standard competencies/basic competencies/ indicators, determine the media and learning sources, as well as developing the learning materials. Meanwhile, their ability in formulating the objective of the learning, determine the methods and strategy, determine the activity steps, and develop learning evaluation are still in moderate category. The interview held with several certified teachers reveal that their syllabus/RPP was mostly they copied them from others 
or that it was prepared by the central office of education. Thus, it means that the syllabus/lesson plans have never been done. The excuse for this is that they do not have time and they rarely participate in trainings for syllabus/lesson plan development.

\section{Evaluation of the quality of the lesson implementation}

The observation on the ability of certified teachers in managing the lesson implementation is presented in the following Table 4.

Based on Table 4 above, it is clear that out of five observed components on the aspects of learning activity implementation by certified teachers in SMPN 6 Luwuk, the result was only moderate. This means that in average the quality of certified teachers' performance in implementing the learning tend to be less optimum; especially in the aspect of opening the lesson, exploring the lesson, elaborating the lesson, confirming the lesson and closing the lesson. Based on the observation within the class during the learning session, many of the certified teachers were not consistent with their lesson plan that they had previously made. There were also teachers who did not implement apperception in their opening activities. From the several interview with certified teachers, they revealed that they have no initiative and no creativity in teaching, because their learning media was only whiteboard. In addition, their methods of delivering the lesson were only focused on lecture, tasks assignment, or discussion.

\section{DISCUSSION}

\section{Quality of Certified Teachers' Performance in Planning The Lesson (syllabus)}

The success of education is determined by the readiness of teachers in preparing their students through learning activities. The goal of this research is to know the implementation of the performance evaluation of teachers (Harjali, 2016). More than one decade it became a material debate related to the teachers' certification and and their affectiveness (Darling-Hammond et al., 2005; Kanea, Rockoff, and Staiger, 2008). Even some findings suggest that there is a positive impact of certification on education (Darling-Hammond\&

Table 3. Recapitulation of the observation/assessment result of the lesson plan documents (syllabus) of certified teachers in SMPN6 Luwuk

\begin{tabular}{|c|c|c|c|c|c|c|c|c|}
\hline \multirow[t]{2}{*}{ No. } & \multirow[t]{2}{*}{ Evaluated components } & \multirow{2}{*}{$\begin{array}{c}\text { Item } \\
\text { descriptor }\end{array}$} & \multicolumn{4}{|c|}{ Evaluation results (\%) } & \multirow[t]{2}{*}{ Total score $(\%)$} & \multirow[t]{2}{*}{ Qualification } \\
\hline & & & 1 & 2 & 3 & 4 & & \\
\hline 1 & $\begin{array}{l}\text { Ability to develop competencies } \\
\text { standard (SK) }\end{array}$ & 1 & - & - & 68.75 & 31.25 & 83 & Good \\
\hline 2 & $\begin{array}{l}\text { Ability to develop basic } \\
\text { competencies (KD) }\end{array}$ & 2 & - & - & 87.5 & 12,5 & 78 & Good \\
\hline 3 & $\begin{array}{l}\text { Ability to describe learning } \\
\text { indicators }\end{array}$ & $3-5$ & - & - & 100 & - & 75 & Good \\
\hline 4 & $\begin{array}{l}\text { Ability to formulate the learning } \\
\text { objectives }\end{array}$ & $6-10$ & - & 37.5 & 62.5 & - & 66 & Moderate \\
\hline 5 & $\begin{array}{l}\text { Ability to develop learning } \\
\text { materials }\end{array}$ & $11-15$ & - & - & 100 & - & 75 & Good \\
\hline 6 & $\begin{array}{l}\text { Ability to determine/select } \\
\text { strategy/methods }\end{array}$ & $16-19$ & 12.5 & 68.75 & 18.75 & - & 52 & Moderate \\
\hline 7 & $\begin{array}{l}\text { Ability to determine the activity } \\
\text { steps }\end{array}$ & $20-23$ & - & 31.25 & 68.75 & - & 67 & Moderate \\
\hline 8 & $\begin{array}{l}\text { Ability to determine media and } \\
\text { source of learning }\end{array}$ & $24-26$ & - & 25 & 68.75 & - & 70 & Good \\
\hline 9 & $\begin{array}{l}\text { Ability to compose learning } \\
\text { evaluation }\end{array}$ & $27-30$ & 12.5 & 37.5 & 43.75 & - & 61 & Moderate \\
\hline
\end{tabular}

Table 4. Summary of the observation/assessment on certified teachers at SMPN6 Luwuk in lesson implementation

\begin{tabular}{|c|c|c|c|c|c|c|c|c|}
\hline \multirow[t]{2}{*}{ No. } & \multirow[t]{2}{*}{ Evaluated component } & \multirow{2}{*}{$\begin{array}{c}\text { Item } \\
\text { descriptor }\end{array}$} & \multicolumn{4}{|c|}{ Evaluation results $(\%)$} & \multirow[t]{2}{*}{ Total score $(\%)$} & \multirow[t]{2}{*}{ Qualification } \\
\hline & & & 1 & 2 & 3 & 4 & & \\
\hline 1 & Ability in opening the lesson & $1-5$ & 6.25 & 12.5 & 81.25 & - & 69 & Moderate \\
\hline 2 & Teacher's ability in exploring the lesson & $6-10$ & 6.25 & 68.75 & 25 & - & 55 & Moderate \\
\hline 3 & Teacher's ability in elaborating the lesson & $11-19$ & - & 56.25 & 43.75 & - & 61 & Moderate \\
\hline 4 & Ability to confirm the lesson & $20-25$ & - & 56.25 & 43.75 & - & 61 & Moderate \\
\hline 5 & Ability to close the lesson session & $26-30$ & - & 31.25 & 68.75 & - & 67 & Moderate \\
\hline
\end{tabular}


MacDonald, 2000; Wenglinsky, 2000; Wilson, Floden, \& Ferrini-Mundy, 2001).

Professional teachers that is the ability of the teacher is the ability to plan the learning program (Ilyas, 2009), the ability of teacher in planning the lesson is preparing the syllabus. Therefor, a teacher should show creativity, as Robbins and Coulter (2005) says creativity is the ability to produce new ideas.

Syllabus is part of the lesson kit and is a guideline in developing the lesson plan because all aspects of learning are written in them. The differences in situation, and social condition, school and learners' condition, culture in a region influence the learning. Therefore, they could be used as the basis for why syllabus development is needed, in order to study the standard competencies and the basic competencies stipulated within the Standard Content (SI) of education. Teachers are then required to further develop the materials, learning experience, indicators, techniques and instruments, and select appropriate source of learning for a qualified syllabus can be implemented and be accountable for.

Developing syllabus without further development has been a habit for teachers in SMPN6 Luwuk, time and knowledge constraints in developing the syllabus are the excuse for why teachers do not develop their syllabus. According to Semiawan, (1985) as an instructional system, there are several components in teaching namely, teaching objectives, teaching materials, teaching method, teaching tools and teaching media, evaluation of teaching and teaching situation. Certified teachers are fully aware that they should develop lesson syllabus as part of their efforts in increasing the quality of education in their school.

The observation had revealed that the quality of lesson plan composed by certified teachers is no different from those composed by non-certified teachers, in which, they have written down all the required components of learning. This we can observe when certified teachers and uncertified teachers were low in making the lesson plans, it is clear that there is no difference between certified teachers and uncertified teachers in the preparation of lesson plans, and recently it was noticed that this was influenced by the teacher's creativity in designing a lesson plans. According to Ilyas (2009) that professional teachers are teachers who can design a program plan of learning. Obviously this is a very critical issue where the quality of teachers is questionable in the preparation of learning programs or performance in planning the lesson (Betts, Rueben, \& Danenberg, 2000; Darling-Hammond, et al., 2005; Darling-Hammond \& MacDonald, 2000).

However, they have not developed most of those components, for instance, the method or learning strategy do not change at all, despites the possibility of developing the learning strategy to suit the result of the evaluation or important experiences in learning process can be a good stimulus to adjust the learning strategy. In learning material aspect, the material development was also not evident and so far they just copied the material from text book, and in assessment instrument aspect were also dominated by the assessment in cognitive area.
These findings should not have happened, because professional teachers are supposed to be able and skillful in developing the lesson plan and not merely copying the lesson plan made by others. Worse, the lesson plan proposed to be signed and approved by the school principal was the lesson plan from the previous year without any development. Regardless that there is nothing that prohibits the teachers from proposing the same lesson plan, as professional teachers, they are supposed to be able to develop the lesson plan as part of their duties that is to plan the lesson.

Quality of lesson plan made by uncertified teachers is no different than those made by certified teachers. In other words, that the professional teacher's title held by certified teachers had not made any difference in turning the development of lesson plan to a better direction. Quality of lesson plan largely determines the quality of basic competencies achieved within the learning process because all learning activities are reflected in the lesson plan. This is a critical issue, where the findings associated with highly different certified teachers in Banggai Regency with previous studies (See for example: Darling-Hammond \& MacDonald, 2000; Monk, 1994; Betts, Rueben, \& Danenberg, 2000; Wenglinsky, 2000; Wilson, Floden, \& Ferrini-Mundy, 2001).

\section{CONCLUSION}

Based on the findings and discussion of this research, the following conclusion is reached:

1. Performance quality of certified teachers in SMPN6 Luwuk of Banggai Regency in planning the lesson was in low category. This means that the certification process has not yet given the positive contribution toward the increase of the performance of certified teachers in SMPN6 Luwuk based on the quality of their performance in planning the lesson.

2. Quality of the certified teachers' performance in SMPN6 Luwuk of Banggai Regency in implementing the learning activities overall was in low category. This means that the teacher's certification process has not yet positively contribute to the increase of certified teachers' performance in SMPN6 Luwuk based on the quality of their performance in managing the lesson activity.

3. Need to investigate the assessment quality of learning outcomes, the role of teachers in the development of potential leaners and the attitude of certified teacher discipline.

\section{ACKNOWLEDGEMENTS}

The Author would like to thanks to the Chief-Editor of IJELS and Expert Reviewers for very helpful comments and the critical evaluation of the main contens on an earlier draft of this paper.

\section{REFERENCES}

Betts, J.R., Rueben, K.S., \& Danenberg, A. (2000). Equal resources, equal outcomes? Thedistribution of school resources and student achievement in California. San Francisco: PublicPolicy Institute of California. 
Darling-Hammond, L., \& MacDonald, M. (2000). Where there is learning there is hope: The preparation of teachers at the Bank Street College of Education. In L. Darling-Hammond (Ed.), Studies of excellence in teacher education: Preparation at the graduatelevel (pp. 1-95). Washington, DC: American Association of Colleges for Teacher Education.

Darling-Hammond,L., Holtzman,D.J., Gatlin,S.J., \& Heilig, J.V. (2005). Does teacher preparation matter? Evidence about teacher certification, Teach for America, and teacher effectiveness. Education Policy Analysis Archives, 13(42), 1-48.

Dale, T, A. (2000). Produktivitas, Seri Manajemen Sumber Daya Manusia. Jakarta: PT. Elex Media Komputindo Kelompok Gramedia.

Dinas Pendidikan Pemuda dan Olahraga. (2011). Data Kabupaten Banggai. Depdikbud. Luwuk Banggai.

Djali, P. M., and Ramly. (2000). PengukurandalamPendidikan. PPS UNJ. Jakarta.

GovernmentRegulation No. 37 of 2009 on Lecturers. (2009). Jakarta: Novindo Pustaka Mandiri. Jakarta

Ilyas, I. (2009). Kinerja-dan-Kompetensi-guru/teacher's performance and competencies. Vol.11. Http:// ilyasismailputrabugis.blogspot.com/2009/11/Kinerja-dan-Kompetensi-guru.html.

Terry, G. R. (1993). PengembanganSumberDayaManusia. Yogyakarta: Liberty.

Harjali (2016) Implementasi Evaluasi Kinerja Guru Di MA Al-Islam Joresan MLARAK Ponorogo. Jurnal pendidikan islam. Vol. 10 No. 1. April 2016.

Hussaini, U. (2006). Manajemen, Teori, Praktek, dan Riset Pendidikan. Bumi aksara.

Moleong, J. L. (2004).MetodologiPenelitianKualitatif. Bandung: PT Remaja Rosda karya.

Kenneth (1988). Management of Organizational Behavior Utilizing Human Resources. New Delhi: Prentice Hall.

Landy \& Fan (2000). Penilaian Kinerja. Yogyakarta: ANDI.

Manullang, M. (2001). ManajemenPersonalia. Yogyakarta: Gajah Mada University Press.

Micthell. T. R. (1989). People in Organization Understanding their Behavior. International student Edition Mc. Graw Hill kogakhusa.

Monk, D.H. (1994). Subject area preparation of secondary mathematics and science teachers andstudent achievement. Economics of Education Review, 13(2), 125-145.
Mulyasa. (2009). Standar Kompetensi dan Sertifikasi Guru. Bandung: Remaja Rosda karya.

Paul D. S. and Dean B. (2002).Organizational Behavior, Solutions forManagement. International Edition. New York: McGraw-Hill/Irwin.

Patricia,K. (1993). Performance planning \& Appraisal: A How-To Book for Manager.New York St. Louis San Francisco: McGrawhill Book Company.

Regulation National Education System. (2009).UU RI No. 20 Th. 2003. Jakarta: Sinar Grafika.

Robbins P. S., and Coulter, M. (1999). Manajement. Jakarta: PT. Prenhallindo.

Robert, B. (2001). Performance Management. Jakarta: Gramedia Pustaka Utama.

Serdamayanti. (2001). SumberDayaManusiadanProduktivitasKerja. Bandung: Mandar Maju.

Semiawan, C. (1985). Bagaimana Cara Membina Guru SecaraProfesional. Jakarta: Depdikbud.

Stephan, Robert. (2005).PrilakuOrganisasi.Jakarta: McGraw Hill Salemba Empat.

Stufflebeam, D. L., Forley, W. J., Gephart, W. J., Guba, E. G., Hammond, R. L., Merriman, H. O., \& Provus, M. M. (1971). Educational evaluation and decision making. Fourth Printing. Illinois: F. E. Peacock Publishers, Inc.

Kanea, T. J., Rockoff, J. E., Staiger, D. O. (2008). What does certification tell us about teacher effectiveness? Evidence from New York City. Science Direct. Economics of Education Review 27.615-631.

Uno, H. B. (2009). Profesi Kependidikan. Jakarta: PT. BumiAksara.

Usman, H. (2006).Manajemen, Teori, Praktek, dan Riset Pendidikan. Jakarta: Bumi Aksara.

Wenglinsky, H. (2000). How teaching matters: Bringing the classroom back into discussions ofteacher quality. Princeton, NJ: Educational Testing Service.

Whitmore, J., Dwi, H. P., \& Louis, N. (1997). Coaching for Performance, Seni Mengarahkan untuk mendongkrak kinerja. Jakarta: Gramedia Pustaka Utama.

Wilson, S.M., Floden, R., \& Ferrini-Mundy, J. (2001). Teacher preparation research: Currentknowledge, gaps, and recommendations. A research report prepared for the U.S.Department of Education. Seattle: Center for the Study of Teaching and Policy,University of Washington.

Yamin, M. (2010). Standarisasi Kinerja Guru. Jakarta: Gaung Perseda Press. 